\title{
PENGGUNAAN MODEL PEMBELAJARAN INQUIRI TERBIMBING TERHADAP HASIL BELAJAR SISWA PADA KONSEP SISTEM EKSKRESI PADA MANUSIA DI SMP NEGERI 2 KOTA BANDA ACEH
}

\author{
Nurlena Andalia $^{1 \text { a) }}$, Armi ${ }^{2)}$, Nurul Akmal', Muhammad Ridhwan ${ }^{\text {() }}$ \\ 1) 2) 3) ${ }^{4}$ Pendidikan Biologi FKIP Universitas Serambi Mekkah, Jl. Tengku Imum Lueng Bata Desa \\ Batoh, Kec. Lueng Bata Kota Banda Aceh \\ ${ }^{a)}$ nurlena.andalia@serambimekkah.ac.id \\ Telp: $+62-822-7444-4718$
}

\begin{abstract}
This study aims to find out the use of the Guided Inquiry learning model in improving student learning outcomes on the concept of excretion systems in humans in Banda Aceh City 2 Middle School. Data processing method is done by validity test, reliability test, normality test, homogeneity test and followed by t-test. The results of the study show that there is a difference between the application of a guided inquiry model and conventional methods towards student learning outcomes in the concept of excretion systems in humans. The acquisition of the difference value (gain) in the experimental class is 14.24 with an $\mathrm{N}$-gain value of 0.44 and the control class is 5.42 with an $\mathrm{N}$-gain value of 0.27 . The results of the t-test obtained by the value of tcount of 2.14 and t table 1.68023 so that $\mathrm{t}$-count $>\mathrm{t}$-table. the average activity of students during learning has been done well, where activities carried out by students in the category of less (7.14\%), good category $(57.14 \%)$ and in the category is very good (35.72\%). So the results of this study can be concluded that the application of the guided inquiry learning model influences the improvement of student learning outcomes in the concept of excretion systems in humans in class VIII of SMP Negeri 2 Kota Banda Aceh.
\end{abstract}

Key words : Guided inquiry model, conventional model, excretion system

\begin{abstract}
ABSTRAK
Penelitian ini bertujuan untuk mengetahui penggunaan model pembelajaran Inquiri Terbimbing dalam meningkatkan hasil belajar siswa pada konsep sistem ekskresi pada manusia di SMP Negeri 2 Kota Banda Aceh. Metode pengolahan data dilakukan dengan uji validitas, uji reliabilitas, uji normalitas, uji homogenitas dan dilanjutkan dengan uji-t. Hasil penelitian menunjukkan bahwa adanya perbedaan antara penerapan model Inquiri terbimbing dengan metode konvensional tershadap hasil belajar siswa pada konsep sistem ekskresi pada manusia. Perolehan nilai rata-rata selisih (gain) pada kelas eksperimen adalah 14,24 dengan nilai $\mathrm{N}$-gain 0,44 dan kelas kontrol adalah 5,42 dengan nilai $\mathrm{N}$-gain 0,27 . Hasil uji-t diperoleh nilai $\mathrm{t}_{\text {hitung }}$ sebesar 2,14 dan $\mathrm{t}_{\text {tabel }} 1.68023$ sehingga $\mathrm{t}_{\text {-hitung }}>\mathrm{t}_{\text {tabel }}$. rata-rata aktivitas siswa selama pembelajaran sudah dilakukan dengan baik, dimana kegaiatan yang dilakukan siswa pada kategori kurang $(7,14 \%)$, kategori baik $(57,14 \%)$ dan pada ketegori sangat baik $(35,72 \%)$. Jadi hasil penelitian ini dapat disimpulkan bahwa penerapan model pembelajaran inquiri terbimbing berpengaruh terhadap peningkatan hasil belajar siswa pada konsep sistem ekskresi pada manusia di kelas VIII SMP Negeri 2 Kota Banda Aceh.
\end{abstract}

Kata Kunci : $\quad$ Model inquiri terbimbing, model konvensional, sistem ekskresi 


\section{PENDAHULUAN}

Pendidikan adalah sebuah proses pembelajaran baik melalui kegiatan formal, informal maupun formal yang tujuannya tidak lain adalah untuk pengembangan diri individu, untuk menguasi berbagai aspek baik kognitif, afektif dan psikomotorik. Kegiatan pendidikan bukan hanya dilakukan dan difasilitasi oleh guru di sekolah tetapi juga oleh orang tua, keluarga dan lingkungan. (Darmaningtyas 2005: 198).

Selama ini pelaksanaan pembelajaran di sekolah lebih ber fokus kepada guru (teacher centered), sehingga dalam proses pembelajaran, guru lebih mendominasi dan menjadi pusat kegiatan dalam pembelajaran. Siswa diibaratkan sebagai gelas kosong yang diisi air oleh guru. Wina Sanjaya (2010: 76) menyebutkan bahwa dalam kegiatan pembelajaran sering muncul beberapa masalah yaitu di dalam proses pembelajaran, guru hanya menggunakan komunikasi satu arah sehingga cenderung akan membuat siswa menjadi pasif karena guru tidak berusaha mengajak siswa untuk berpikir. Berdasarkan hasil observasi awal diketahui pelaksanaan pembelajaran di SMP Negeri 2 Kota Banda Aceh belum seperti yang diharapkan, proses pembelajaran masih belum mampu memberikan hasil yang maksimal bagi siswa. Hasil pengamatan penulis, menunjukkan hasil belajar siswa kelas VIII terindikasi masih rendah. Siswa yang mencapai ketuntasan belajar hanya $60 \%$, sedangkan $40 \%$ siswa belum tuntas dalam mengerjakan materi (KKM 70\%).

Permasalahan di SMP Negeri 2 Kota Banda Aceh tampaknya disebabkan oleh dua faktor yaitu faktor dalam diri siswa seperti bakat, minat, intelegensi dan faktor di luar siswa salah satunya adalah guru. Penerapan model atau metode pembelajaran yang tidak tepat membuat siswa jenuh dan bosan mengikuti suatu materi pelajaran. Hal ini berdampak pada rendahnya hasil belajar siswa.

Salah satu cara meningkatkan prestasi belajar pada siswa adalah melalui model inkuiri. Menurut Sanjaya, (2006:24). "Kata inkuiri berarti menyelidiki dengan cara mencari informasi dan melakukan pertanyaanpertanyaan. Dengan pendekatan atau model inkuiri ini siswa diharapkan aktif belajar, melibatkan diri dalam berbagai kegiatan dan mampu menyelesaikan tugas tersendiri". Menurut Mulyasa (2003:234) "model inkuiri adalah metode yang mampu menggiring peserta didik untuk menyadari apa yang telah didapatkan selama belajar. Inkuiri menempatkan peserta didik sebagai subyek belajar yang aktif". Sedangkan menurut Subroto (2002:192) "Inkuiri adalah perluasan proses discovery yang digunakan lebih mendalam. Artinya proses inkuiri mengandung proses-proses mental yang lebih tinggi tingkatnya, misalnya: merumuskan problema, merancang eksperimen, melakukan eksperimen, mengumpulkan dan menganalisa data, menarik kesimpulan dan lain sebagainya".

Permasalahan di SMP Negeri 2 Kota Banda Aceh memerlukan upaya penyelesaian agar siswa menjadi termotivasi untuk mempelajari materi keberagaman suku bangsa dan budaya sehingga tercapainya ketuntasan belajar siswa. Alternatif untuk memecahkan masalah tersebut di atas adalah dengan menggunakan model atau metode pembelajaran yang dapat menarik minat siswa untuk belajar. Dengan penerapan model pembelajaran tersebut diharapkan siswa menjadi termotivasi sehingga bisa menuntaskan hasil belajar siswa dan berdampak pada meningkatnya kompetensi siswa. Berdasarkan uraian di atas peneliti tertarik untuk melakukan penelitian ini.

\section{METODELOGI PENELITIAN}

Pendekatan yang digunakan dalam penelitian ini adalah pendekatan kuantitatif. "Pendekatan kuantitatif adalah suatu data penelitian yang berupa angka-angka dan analisis dengan menggunakan statistik" (Sugiyono, 2010:13). Sedangkan Jenis penelitian adalah eksperimen yang digunakan untuk mencari pengaruh perlakuan tertentu terhadap yang lain dalam kondisi yang terkendalikan (Sugiyono, 2010 : 18).

Desain penelitian merupakan rancangan bagaimana penelitian dilaksanakan. Penelitian ini menggunakan desain pretestposttest control group design dengan format disajikan pada tabel berikut (Tabel 1). 
Table 1. Desain Pretest-Posttest Control Group Design

\begin{tabular}{clccc}
\hline Sampel & \multicolumn{1}{c}{ Kelompok } & Pretes & Perlakuan & postes \\
\hline Acak & $\mathrm{B}$ (eksperimen) & $\mathrm{O}_{1}$ & $\mathrm{X}$ & $\mathrm{O}_{2}$ \\
\hline Acak & $\mathrm{A}$ (kontrol) & $\mathrm{O}_{3}$ & - & $\mathrm{O}_{4}$ \\
\hline
\end{tabular}

Keterangan:

O1 : Hasil pre-test kelas eksperimen

O2 : Hasil post-test kelas eksperimen

O3 : Hasil pre-test kelas kontrol

$\mathrm{O} 4$ : Hasil post-test kelas kontrol

$\mathrm{X}$ : Perlakuan pada kelas eksperimen dengan penggunaan model pembelajaran inkuiri terbimbing.

- $\quad$ : Perlakuan pada kelas kontrol dengan penggunaan pembelajaran

konvensional. (Sugiyono, 2011: 76)

Dari desain penelitian di atas dapat dijelaskan bahwa dari dua kelas yang setara ditetapkan pengelompokkan kelas ke dalam dua kelompok yaitu kelompok eksperimen dan kelompok kontrol. Sebelum eksperimen dilaksanakan, terlebih dahulu diadakan pretest untuk kelompok eksperimen yang dikenai perlakuan (treatment) maupun kelompok kontrol yang tidak dikenai perlakuan. Kemudian pada kelompok eksperimen diterapkan pembelajaran dengan menggunakan model pembelajaran inkuiri terbimbing. Sedangkan pada kelompok kontrol diterapkan pembelajaran dengan metode konvensional.
Selama proses pembelajaran diadakan pengamatan untuk mengukur keaktifan belajar siswa. Di akhir pembelajaran diadakan posttest pada kelompok eksperimen maupun kelompok kontrol untuk mengukur hasil belajar siswa.

\section{Tempat dan Waktu Penelitian}

Penelitian ini dilaksanakan di SMP Negeri 2 Kota Banda Aceh, adapun waktu penelitian telah dilaksanakan pada tanggal 29 Januari s/d 05 Februari 2017, yaitu pada semester genap tahun ajaran 2016/2017.

\section{Populasi dan Sampel Penelitian}

Sugiyono (2011: 80) menyatakan bahwa populasi adalah wilayah generalisasi yang terdiri atas obyek/subyek yang mempunyai kualitas dan karakteristik tertentu yang ditetapkan oleh peneliti untuk dipelajari dan kemudian ditarik kesimpulannya. Dalam penelitian ini, yang menjadi populasi adalah seluruh siswa-siswi kelas VIII SMP Negeri 2 Kota Banda Aceh tahun ajaran 2016-2017 dengan jumlah siswa sebanyak 198 orang siswa yang terdiri dari 8 kelas. Adapun jumlah siswa tercantum pada tabel sebagai berikut:

Tabel 2 . Data Siswa Masing-masing Kelas VIII SMP Negeri 2 Kota Banda Aceh

\begin{tabular}{|c|c|c|c|c|}
\hline \multirow{2}{*}{ No } & \multirow{2}{*}{ Kelas } & \multicolumn{2}{|c|}{ Populasi } & \multirow{2}{*}{ Jumlah siswa/kelas } \\
\hline & & Laki-laki & Perempuan & \\
\hline 1 & VIII-1 & 10 & 14 & 24 \\
\hline 2 & VIII-2 & 14 & 13 & 27 \\
\hline 3 & VIII-3 & 12 & 10 & 22 \\
\hline 4 & VIII-4 & 12 & 12 & 24 \\
\hline 5 & VIII-5 & 12 & 13 & 25 \\
\hline 6 & VIII-6 & 11 & 13 & 24 \\
\hline 7 & VIII-7 & 13 & 13 & 26 \\
\hline \multirow[t]{2}{*}{8} & VIII-8 & 14 & 12 & 26 \\
\hline & Jumlah & 98 & 100 & 198 \\
\hline
\end{tabular}

Sumber : Data siswa SMP Negeri 2 Kota Banda Aceh tahun 2016

Menurut Sugiyono (2011:81) sampel merupakan bagian dari jumlah dan karakteristik yang dimiliki oleh populasi dan bisa mewakili populasi tersebut. Oleh karena itu, sampel yang dipilih dari populasi harus betul-betul representatif. Salah satu syarat dalam penarikan sampel adalah bahwa sampel itu harus bersifat representatif, artinya sampel 
yang diterapkan harus mewakili populasi. Sifat dan karakteristik populasi harus tergambar dalam sampel.

Atas dasar teori tersebut, Sebagai sampel ditentukan secara tegas kelas VIII yang diambil yaitu kelas VIII-3 ditetapkan sebagai kelas eksperimen yang diajarkan dengan model pembelajaran inquiri terbimbing dan kelas VIII-4 sebagai kelas kontrol yang diajarkan dengan menggunakan metode konvensional pada konsep yang sama yaitu konsep sistem ekskresi pada manusia.

\section{Teknik Pengumpulan Data}

\section{Observasi}

$$
\text { Nana Syaodih (2009: 220) }
$$

mengemukakan bahwa "observasi atau pengamatan merupakan suatu teknik atau cara mengumpulkan data dengan jalan mengadakan pengamatan terhadap kegiatan yang sedang berlangsung". Peneliti melakukan pengamatan dan pencatatan mengenai keaktifan belajar siswa selama proses pembelajaran berlangsung tanpa mengganggu kegiatan belajar mengajar.

2. Tes

$\begin{array}{clr}\text { Menurut } & \text { Suharsimi } & \text { Arikunto } \\ (2006: 127) \text { "tes } & \text { merupakan } & \text { serentetan }\end{array}$
pertanyaan atau latihan atau alat lain yang digunakan untuk mengukur keterampilan, pengetahuan, intelegensi, kemampuan atau bakat yang dimiliki oleh individu atau kelompok". Dalam penelitian ini yang akan diukur adalah prestasi belajar siswa. Tes prestasi belajar yang dilakukan dalam penelitian ini menggunakan pre-test dan posttest. Tes awal (pre-test) digunakan untuk mengetahui kemampuan awal siswa sebelum perlakuan diterapkan. Sedangkan tes akhir (post-test) digunakan untuk mengetahui kemampuan akhir atau hasil belajar siswa setelah perlakuan (treatment).

\section{Teknik Analisis Data}

Setelah semua data yang diperoleh dalam penelitian ini terkumpul maka data diolah dengan rumus uji-t, dengan langkahlangkah sebagai berikut:

\section{Uji Validitas}

Uji validitas merupakan ukuran seberapa tepat dan cermat suatu alat ukur melakukan fungsi ukurnya. Uji ini digunakan untuk menguji validitas dari kuisioner serta membuktikan apakah setiap butir kuisioner benar-benar telah mengukur konsep yang dimaksudkan (Sugiyono, 2013:102). Validitas korelasi dilakukan dengan perhitungan menggunakan rumus Pearson sebagai berikut:

$$
r_{x}=\frac{N \sum X Y-\left(\sum X\right)\left(\sum Y\right)}{\sqrt{\left\{N \sum X^{2}-\left(\sum X\right)^{2}\right\}\left\{N \sum Y^{2}-\left(\sum Y\right)^{2}\right\}}}
$$

$\mathrm{X} \quad=$ Skor yang diperoleh subyek dari seluruh item

$\mathrm{Y}=$ Skor total yang diperoleh dari seluruh item

$\Sigma \mathrm{X}=$ Jumlah skor dalam distribusi $\mathrm{X}$

$\Sigma \mathrm{Y}=$ Jumlah skor dalam distribusi $\mathrm{Y}$

$\Sigma \mathrm{X} 2$ = Jumlah kuadrat dalam skor distribusi

$\mathrm{X}$

$\Sigma Y 2$ = Jumlah kuadrat dalam skor distribusi

$\mathrm{Y}$

$\mathrm{N}$ = Banyaknya responden

Item Instrumen dianggap valid dengan membandingkannya dengan r-hitung dengan $\mathrm{r}$ tabel. Jika r-hitung > r-tabel maka instrumen dikatakan valid.

\section{Uji Reliabilitas}

Menurut Suharsimi Arikunto (2013:100) mengemukakan bahwa reliabilitas berhubungan dengan masalah kepercayaan. Suatu tes dapat dikatakan mempunyai taraf kepercayaan yang tinggi jika tes tersebut dapat memberikan hasil yang tetap.Tuntutan bahwa instrument evaluasi harus valid menyangkut harapan yang diperolehnya data yang valid, sesuai dengan kenyataan. Jika validitas terkait dengan ketepatan objek yang tidak lain adalah tidak menyimpangnya dari kenyataan, artinya bahwa data tersebut benar. Untuk menguji reliabilitas tes hasil belajar dalam hal ini digunakan rumus sebagai berikut :

$$
\begin{array}{ll}
r_{11}=\left(\frac{k}{k-1}\right)\left(1-\frac{\sum \sigma_{2}^{2}}{\sigma_{1}^{2}}\right) \\
\mathrm{r}_{11} \quad=\text { nilai reliabilitas } \\
\mathrm{k} \quad=\text { banyaknya butir soal } \\
\mathrm{N} \quad=\text { banyaknya responden } \\
\sigma_{b}^{2} & =\text { total varian } \\
\Sigma o_{b}^{2} & =\text { total varian butir }
\end{array}
$$

Reliabilitas suatu konstruk variabel dikatakan baik jika memiliki nilai Alpha Cronbach's $>0,60$. Jadi pengujian reliabilitas instrument dalam penelitian dilakukan karena keterandalan instrumen berkaitan dengan keajegan dan taraf kepercayaan terhadap instrumen penelitian tersebut.

\section{Uji Normalitas}

Uji normalitas merupakan uji yang dilakukan sebagai prasyarat untuk melakukan analisis data. Uji normalitas dilakukan 
sebelum data diolah berdasarkan model-model penelitian yang diajukan. Uji normalitas data bertujuan untuk mendeteksi distribusi data dalam satu variabel yang akan digunakan dalam penelitian. Data yang baik dan layak untuk membuktikan model-model penelitian tersebut adalah data distribusi normal. Uji normalitas yang digunakan adalah uji Kolmogorov-Smirnov. Rumus KolmogorovSmirnova dengan bantuan program SPSS versi 16,0. (Sugiyono, 2013:257). Data dikatakan normal, apabila nilai signifikan lebih besar 0,05 pada $(\mathrm{P}>0,05)$. Sebaliknya, apabila nilai signifikan lebih kecil dari 0,05 pada $(\mathrm{P}<0,05)$, maka data dikatakan tidak normal

\section{Uji homogenitas}

Uji homogenitas digunakan untuk memperlihatkan bahwa dua atau lebih kelompok data sampel berasal dari populasi yang memiliki variasi yang sama. Uji homogenitas dikenakan pada data hasil posttest dari kelompok eksperimen dan kelompok kontrol. Untuk mengukur homogenitas varians dari dua kelompok data, digunakan rumus uji F sebagai berikut :

$F=\frac{\text { Varian terbesar }}{\text { Varian terkecil }}$

(Sugiyono, $2013: 276$ )

Taraf signifikasi yang digunakan adalah $\alpha=0,05$. Uji homogenitas menggunakan SPSS dengan kriteria yang digunakan untuk mengambil kesimpulan apabila $\mathrm{F}$ hitung lebih besar dari $\mathrm{F}$ tabel maka memiliki varian yang homogen. Akan tetapi apabila $\mathrm{F}$ hitung lebih besar dari $\mathrm{F}$ tabel, maka varian tidak homogen.

Perhitungan Normalized gain bertujuan untuk mengetahui peningkatan pemahaman siswa pada pelajaran biologi. Perhitungan tersebut diperoleh dari nilai pretest dan post-test masing-masing kelas yaitu kelas eksperimen dan kelas kontrol. Dalam penelitian ini, Normalized gain akan digunakan apabila rata-rata post-test kelas kontrol dan kelas eksperimen berbeda. Peningkatan yang terjadi sebelum dan sesudah pembelajaran dihitung dengan rumus Normalized gain ( $N$-Gain) dengan rumus sebagai berikut:

$$
\begin{aligned}
& \mathrm{N} \text {-gain }=\frac{N B-N A}{N_{\text {maks }}-N A} \text { (Meltzer, 2002) } \\
& \text { Keterangan : } \\
& \text { N-gain = Peningkatan nilai } \\
& N A \quad=\text { Skor } \text { pre-test }
\end{aligned}
$$

$$
\begin{array}{ll}
N B & =\text { Skor pos-ttest } \\
N_{\text {maks }} & =\text { Skor maksimal } / \text { ideal }
\end{array}
$$

Dengan kategori perolehan N-Gain :

Tinggi : N-Gain > 70;

Sedang : $30 \leq \mathrm{N}-$ Gain $\leq 70$;

Rendah : N-Gain < 30.

Skor rata-rata gain normalisasi $(\mathrm{N}-$ Gain) antara kelas eksperimen dan kelas kontrol digunakan sebagai data untuk membandingkan kemampuan hasil belajar. Perbedaan kedua rata-rata antara kedua kelas dilakukan dengan "uji-t".

\section{Uji Hipotesis}

Pengujian hipotesis digunakan untuk menguji kebenaran dari hipotesis yang telah diajukan pada penelitian ini diterima atau tidak. Pengujian hipotesis ini dihitung dengan menggunakan rumus uji-t (Sudjana, 2005:123), yaitu :

$$
\mathrm{t}=\frac{\bar{X}_{1-} \bar{X}_{2}}{\sqrt[s]{\frac{1}{n_{1}}+\frac{1}{n_{2}}}}
$$

Keterangan:

$\mathrm{X}_{1}=$ Nilai rata-rata kelas eksperimen pertama

$\mathrm{X}_{2}=$ Nilai rata-rata kelas eksperimen kedua

$\mathrm{S}=$ Standar deviasi sehubungan

$\mathrm{n}_{1}=$ Jumlah siswa kelas eksperimen pertama

$\mathrm{n}_{2} \quad=$ Jumlah kelas eksperimen kedua.

Menurut Sugiyono (2008:96) Baik hipotesis deskriptif maupun statistik, dibedakan mejadi hipotesis kerja (Ha) dan hipotesis nol (Ho). Inti dari perbedaan Ha dan Ho yaitu hipotesis kerja dinyatakan dalam kalimat positif sedangkan hipotesis nol dinyatakan dalam kalimat negatif.

1. Hipotesis Kerja (Ha) "penggunaan model pembelajaran Inquiri Terbimbing dapat meningkatkan hasil belajar siswa pada konsep sistem ekskresi pada manusia di SMP Negeri 2 Kota Banda Aceh".

2. Hipotesis Nihil (Ho) "penggunaan model pembelajaran Inquiri Terbimbing tidak dapat meningkatkan hasil belajar siswa pada konsep sistem ekskresi pada manusia di SMP Negeri 2 Kota Banda Aceh”. 


\section{HASIL DAN PEMBAHASAN}

Penelitian ini merupakan penelitian eksperimen dengan desain pretest-posttest control group design yakni menempatkan subyek penelitian ke dalam dua kelompok (kelas) yang dibedakan menjadi kategori kelas eksperimen dan kelas kontrol. Analisis data untuk mengetahui hasil belajar melalui model pembelajaran inquiri terbimbing dan metode konvensional, dilakukan secara kuantitatif. Keefektifan dalam meningkatkan hasil belajar siswa dapat diketahui dari nilai post test antara kelas eksperimen dan kelas kontrol yang berbeda.

\section{Hasil Tes Pemahaman Konsep}

Daftar nilai rata-rata pemahaman siswa kelas VIII-3 dan VIII-4 SMP Negeri 2 Kota Banda Aceh pada pembelajaran konsep sistem ekskresi pada manusia dapat dilihat pada tabel berikut ini:

Tabel 3. Nilai Tes Siswa Kelas Eksperimen dan Kelas Kontrol

\begin{tabular}{|c|c|c|c|c|c|c|c|c|c|c|}
\hline \multirow[b]{2}{*}{ No } & \multirow[b]{2}{*}{ Nama Siswa } & \multicolumn{4}{|c|}{ Kelas Eksperimen } & \multirow[b]{2}{*}{ Nama Siswa } & \multicolumn{4}{|c|}{ Kelas Kontrol } \\
\hline & & Pret & Post & Gain & $\begin{array}{l}\text { N- } \\
\text { Gain }\end{array}$ & & Pret & Post & Gain & $\begin{array}{l}\text { N- } \\
\text { Gain }\end{array}$ \\
\hline 1 & $\begin{array}{l}\text { M. Ilham } \\
\text { Jauersyah }\end{array}$ & 73,33 & 86,67 & 13,33 & 0,80 & $\begin{array}{l}\text { Gine } \\
\text { Riw }\end{array}$ & 70,00 & 73,33 & 3,33 &, 25 \\
\hline 2 & $\begin{array}{l}\text { Farah } \\
\text { Fadhila }\end{array}$ & 70,00 & 90,00 & 20,00 & 1,00 & Natasya & 60,00 & 66,67 & 6,67 & 0,29 \\
\hline 3 & $\begin{array}{l}\text { Nida } \\
\text { Urrahmi }\end{array}$ & 60,00 & 70,00 & 10,00 & 0,33 & $\begin{array}{l}\text { Ririn } \\
\text { Herliana }\end{array}$ & 70,00 & 73,33 & 3,33 & 0,25 \\
\hline 4 & $\begin{array}{l}\text { Dara } \\
\text { Raudhatur } \\
\text { Jannah }\end{array}$ &, 67 & 80,00 & 23,33 & 0,70 & $\mathrm{~A}$ & 76,67 & 83,33 & 6,67 & 1,00 \\
\hline 5 & $\begin{array}{l}\text { M. Indra } \\
\text { Mulya }\end{array}$ & 50,00 & 70,00 & 20,00 & 0,50 & $\begin{array}{l}\text { Ladifa Imara } \\
\text { Fasya }\end{array}$ & 56,67 & 60,00 & 3,33 & 0,13 \\
\hline 6 & $\begin{array}{l}\text { Reza } \\
\text { Ramadhana }\end{array}$ & 40,00 & 63,33 & 23,33 & 0,47 & atun & 63,33 & 66,67 & 3,33 & 0,17 \\
\hline 7 & $\begin{array}{l}\text { Teguh } \\
\text { Ferdinan }\end{array}$ & 60,00 & 80,00 & 20,00 & 0,67 & $\begin{array}{l}\text { Indah } \\
\text { Syahrani }\end{array}$ & 63,33 & 70,00 & 6,67 & 0,33 \\
\hline 8 & $\begin{array}{l}\text { Muhammad } \\
\text { Faruqi H }\end{array}$ & 56,67 & 73,33 & 16,67 & 0,50 & Nurzahara & 56,67 & 63,33 & 6,67 & 0,25 \\
\hline 9 & Roviansyah & 53,33 & 70,00 & 16,67 & 0,45 & $\begin{array}{l}\text { Ayie } \\
\text { Amanda }\end{array}$ & 63,33 & 66,67 & 3,33 & 0,17 \\
\hline 10 & $\begin{array}{l}\text { Rahmat } \\
\text { Trimulya }\end{array}$ & 60,00 & 73,33 & 13,33 & 0,44 & $\begin{array}{l}\text { Anxis Meria } \\
\text { Maita S }\end{array}$ & 56,67 & 63,33 & 6,67 & 0,25 \\
\hline 11 & $\begin{array}{l}\text { Farah Septya } \\
\text { Devy }\end{array}$ & 50,00 & 83,33 & 33,33 & 0,83 & Hafni & 56,67 & 60,00 & 3,33 & 0,13 \\
\hline 12 & $\begin{array}{l}\text { Andryan Al- } \\
\text { Giffari }\end{array}$ & 53,33 & 63,33 & 10,00 & 0,27 & $\begin{array}{l}\text { Hafidh } \\
\text { Arifiansyah }\end{array}$ & 56,67 & 60,00 & 3,33 & 0,13 \\
\hline 13 & $\begin{array}{l}\text { Ayua } \\
\text { Gustina }\end{array}$ & 60,00 & 66,67 & 6,67 & 0,22 & $\begin{array}{l}\text { Rahmadi } \\
\text { Fitria }\end{array}$ & 63,33 & 66,67 & 3,33 & 0,17 \\
\hline 14 & Rosfil Aziz & 56,67 & 73,33 & 16,67 & 0,50 & $\begin{array}{l}\text { Novia } \\
\text { Ramadhani }\end{array}$ & 56,67 & 63,33 & 6,67 & 0,25 \\
\hline 15 & $\begin{array}{l}\text { Febi Yulia } \\
\text { Ananda }\end{array}$ & 60,00 & 70,00 & 10,00 & 0,33 & $\begin{array}{l}\text { Dellyana } \\
\text { Harti Pratiwi }\end{array}$ & 70,00 & 76,67 & 6,67 & 0,50 \\
\hline 16 & $\begin{array}{l}\text { Eka } \\
\text { Mubdiyanti }\end{array}$ & 50,00 & 53,33 & 3,33 & 0,08 & M. Humam & 63,33 & 70,00 & 6,67 & 0,33 \\
\hline 17 & $\begin{array}{l}\text { Hidza } \\
\text { Rivanda }\end{array}$ & 56,67 & 66,67 & 10,00 & 0,30 & $\begin{array}{l}\text { Fajar } \\
\text { Ramadhani }\end{array}$ & 60,00 & 66,67 & 6,67 & 0,29 \\
\hline
\end{tabular}




\begin{tabular}{lllllllllll}
\hline 18 & $\begin{array}{l}\text { Raudatul } \\
\text { Jannah }\end{array}$ & 60,00 & 66,67 & 6,67 & 0,22 & $\begin{array}{l}\text { Anna } \\
\text { Rizatik }\end{array}$ & 60,00 & 63,33 & 3,33 & 0,14 \\
\hline 19 & $\begin{array}{l}\text { Syifa Kanjul } \\
\text { Arasyi }\end{array}$ & 40,00 & 60,00 & 20,00 & 0,40 & Hifzan & 56,67 & 60,00 & 3,33 & 0,13 \\
\hline 20 & $\begin{array}{l}\text { Ulfan } \\
\text { Nafisah }\end{array}$ & 60,00 & 70,00 & 10,00 & 0,33 & $\begin{array}{l}\text { Alzabir } \\
\text { Khalid }\end{array}$ & 63,33 & 70,00 & 6,67 & 0,33 \\
\hline 21 & Putri Baysita & 66,67 & 70,00 & 3,33 & 0,14 & $\begin{array}{l}\text { Ramadian } \\
\text { Putra }\end{array}$ & 50,00 & 70,00 & 20,00 & 0,60 \\
\hline 22 & $\begin{array}{l}\text { Raudhatun } \\
\text { Nadia }\end{array}$ & 63,33 & 70,00 & 6,67 & 0,25 & $\begin{array}{l}\text { Ajis Saipul } \\
\text { A }\end{array}$ & 63,33 & 66,67 & 3,33 & 0,17 \\
\hline 23 & & & & & $\begin{array}{l}\text { M. Firas } \\
\text { Akbar }\end{array}$ & 56,67 & 60,00 & 3,33 & 0,13 \\
\hline 24 & & & & & $\begin{array}{l}\text { Fauzul } \\
\text { Khabir }\end{array}$ & 63,33 & 66,67 & 3,33 & 0,17 \\
\hline & Jumlah & $\mathbf{1 2 5 7}$ & $\mathbf{1 5 7 0}$ & $\mathbf{3 1 3}$ & $\mathbf{9 , 7 6}$ & & $\mathbf{1 4 7 7}$ & $\mathbf{1 6 0 7}$ & $\mathbf{1 3 0}$ & $\mathbf{6 , 5 2}$ \\
\hline & & $\mathbf{5 7 , 1 2}$ & $\mathbf{7 1 , 3 6}$ & $\mathbf{1 4 , 2 4}$ & $\mathbf{0 , 4 4}$ & & $\mathbf{6 1 , 5 3}$ & $\mathbf{6 6 , 9 4}$ & $\mathbf{5 , 4 2}$ & $\mathbf{0 , 2 7}$ \\
\hline
\end{tabular}

Sumber : Data diolah pada tahun 2017

Dari data yang diperoleh, maka penulis menganalisa dengan menggunakan daftar distribusi frekuensi dengan melakukan langkah-langkah sebagai berikut:

1. Menentukan Rentang (R), yaitu nilai tertinggi kurang nilai terendah

2. Menentukan banyak interval (K), yaitu:

$$
\begin{aligned}
& \text { Panjang Kelas }(\mathrm{P}) \\
& =\frac{\text { Rentang }}{\text { Banyak Kelas }}
\end{aligned}
$$

3. Perhitungan Nilai rata-rata (x), Varians $S^{2}$ dan simpangan baku (S)

Nilai selisih post-test kelas eksperimen yang diajarkan dengan penerapan Inquiri terbimbing pada pembelajaran konsep sistem ekskresi pada manusia yaitu 7 .

Berdasarkan data yang diperoleh di atas maka tabel distribusi frekuensi untuk kelas eksperimen seperti terlihat pada tabel berikut ini:

Tabel 4. Daftar Distribusi Frekuensi Nilai Tes Akhir Siswa Kelas Eksperimen

\begin{tabular}{cccccc}
\hline Nilai tes & $\begin{array}{c}\text { Frekuensi } \\
\left(\mathrm{f}_{\mathrm{i}}\right)\end{array}$ & $\begin{array}{c}\text { Titik tengah } \\
(\mathrm{xi})\end{array}$ & $\mathrm{x}_{1}{ }^{2}$ & $\mathrm{f}_{\mathrm{i}} \mathrm{x}_{\mathrm{i}}$ & $\mathrm{f}_{\mathrm{i}} \mathrm{x}_{\mathrm{i}}{ }^{2}$ \\
\hline $53-59$ & 1 & 56 & 3136 & 56 & 3136 \\
\hline $60-66$ & 3 & 63 & 3969 & 189 & 11907 \\
\hline $67-73$ & 13 & 70 & 4900 & 910 & 63700 \\
\hline $74-80$ & 2 & 77 & 5929 & 154 & 11858 \\
\hline $71-87$ & 2 & 74 & 5476 & 148 & 10952 \\
\hline $88-94$ & 1 & 83 & 6889 & 83 & 6889 \\
\hline Jumlah & $\mathbf{2 2}$ & & & $\mathbf{1 5 4 0}$ & $\mathbf{1 0 8 4 4 2}$ \\
\hline
\end{tabular}

\section{Sumber : Data diolah pada tahun 2017}

Berdasarkan tabel di atas dapat ditentukan $\left(\bar{x}_{1}\right), \quad\left(s_{1}^{2}\right)$, dan $(\mathrm{s})$. Maka pengolahan data dilakukan sebagai berikut : $S_{1}=5,52$
Nilai selisih post-test kelas kontrol yang diajarkan dengan menggunakan metode konvensional pada pembelajaran konsep sistem ekskresi pada manusia yaitu 4. 
Berdasarkan data yang diperoleh di atas maka tabel distribusi frekuensi untuk kelas kontrol seperti terlihat pada tabel berikut ini:

Tabel.5 Daftar Distribusi Frekuensi Nilai Tes akhir siswa Kelas Kontrol

\begin{tabular}{cccccc}
\hline Nilai tes & $\begin{array}{c}\text { Frekuensi } \\
\left(\mathrm{f}_{\mathrm{i}}\right)\end{array}$ & $\begin{array}{c}\text { Titik tengah } \\
(\mathrm{xi})\end{array}$ & $\mathrm{x}_{1}{ }^{2}$ & $\mathrm{f}_{\mathrm{i}} \mathrm{x}_{\mathrm{i}}$ & $\mathrm{f}_{\mathrm{i}} \mathrm{x}_{\mathrm{i}}{ }^{2}$ \\
\hline $60-63$ & 9 & 61,5 & 3782,25 & 553,5 & 34040,25 \\
\hline $64-67$ & 7 & 65,5 & 4290,25 & 458,5 & 30031,75 \\
\hline $68-71$ & 4 & 69,5 & 4830,25 & 278 & 19321 \\
\hline $72-75$ & 2 & 73,5 & 5402,25 & 147 & 10804,5 \\
\hline $76-79$ & 1 & 77,5 & 6006,25 & 77,5 & 6006,25 \\
\hline $80-83$ & 1 & 81,5 & 6642,25 & 81,5 & 6642,25 \\
\hline Jumlah & $\mathbf{2 4}$ & & & $\mathbf{1 5 9 6}$ & $\mathbf{1 0 6 8 4 6}$ \\
\hline
\end{tabular}

Sumber : Data diolah pada tahun 2017

Dari tabel dapat ditentukan $\left(\bar{x}_{2}\right),\left(s_{2}^{2}\right)$, dan (s). Maka pengolahan data dilakukan sebagai berikut $S_{2}=5,56$.

Berdasarkan hasil perhitungan nilai selisih tes awal (Pre-test) dan tes akhir (posttest) pada kedua kelas yaitu kelas eksperimen dan kelas kontrol diperoleh rata-ratanya yaitu, untuk kelas eksperimen rata-ratanya $\bar{x}_{1} 70,00$ dan varians $\mathrm{S}_{1}{ }^{2}=30,57$ Sedangkan untuk kelas kontrol diperoleh nilai rata-ratanya $\bar{x}_{2}=66,5$ dan varians $\mathrm{S}_{2}{ }^{2}=30,95$, sebelum dicari $\mathrm{t}_{\text {-hitung }}$ terlebih dahulu dicari standar deviasi gabungan (s). Untuk menghitung deviasi gabungan (s) yaitu dengan cara menggunakan rumus yaitu 5,54 .

\begin{abstract}
Hasil Observasi Pembelajaran
Hasil Observasi Pembelajaran dengan Penerapan Model Pembelajaran Inquiri Terbimbing.

Bedasarkan hasil pengumpulan data dengan lembaran observasi terhadap kegiatan yang dilakukan guru dan siswa selama proses belajar mengajar dengan penerapan model pembelajaran Inquiri terbimbing pada konsep sistem ekskresi pada manusia di kelas konsep sistem ekskresi pada manusia di SMP Negeri 2 Kota Banda Aceh VIII SMP Negeri 2 Kota Banda Aceh dapat dilihat pada tabel berikut ini:
\end{abstract}

Tabel 6. Hasil Obeservasi Aktivitas Siswa Selama Pembelajaran dengan Penerapan Model Pembelajaran Inquiri Terbimbing pada konsep sistem ekskresi pada manusia di SMP Negeri 2 Kota Banda Aceh.

\begin{tabular}{|c|c|c|c|c|c|c|}
\hline \multirow{2}{*}{ No } & \multirow{2}{*}{ Aspek Pengamatan } & \multicolumn{5}{|c|}{ Hasil Observasi } \\
\hline & & SK & $\mathbf{K}$ & $\mathbf{S}$ & $\mathbf{B}$ & SB \\
\hline 1. & Kesiapan siswa menerima materi pelajaran & & & & & $\sqrt{ }$ \\
\hline 2. & Siswa mengerjakan LKPD sesuai Prosedur & & & & & $\sqrt{ }$ \\
\hline 3. & $\begin{array}{l}\text { Siswa berdiskusi dengan anggota kelompoknya } \\
\text { untuk memecahkan permasalahan }\end{array}$ & & & & & $\sqrt{ }$ \\
\hline 4. & Siswa membuat hipotesis (jawaban sementara) & & & & $\sqrt{ }$ & \\
\hline
\end{tabular}




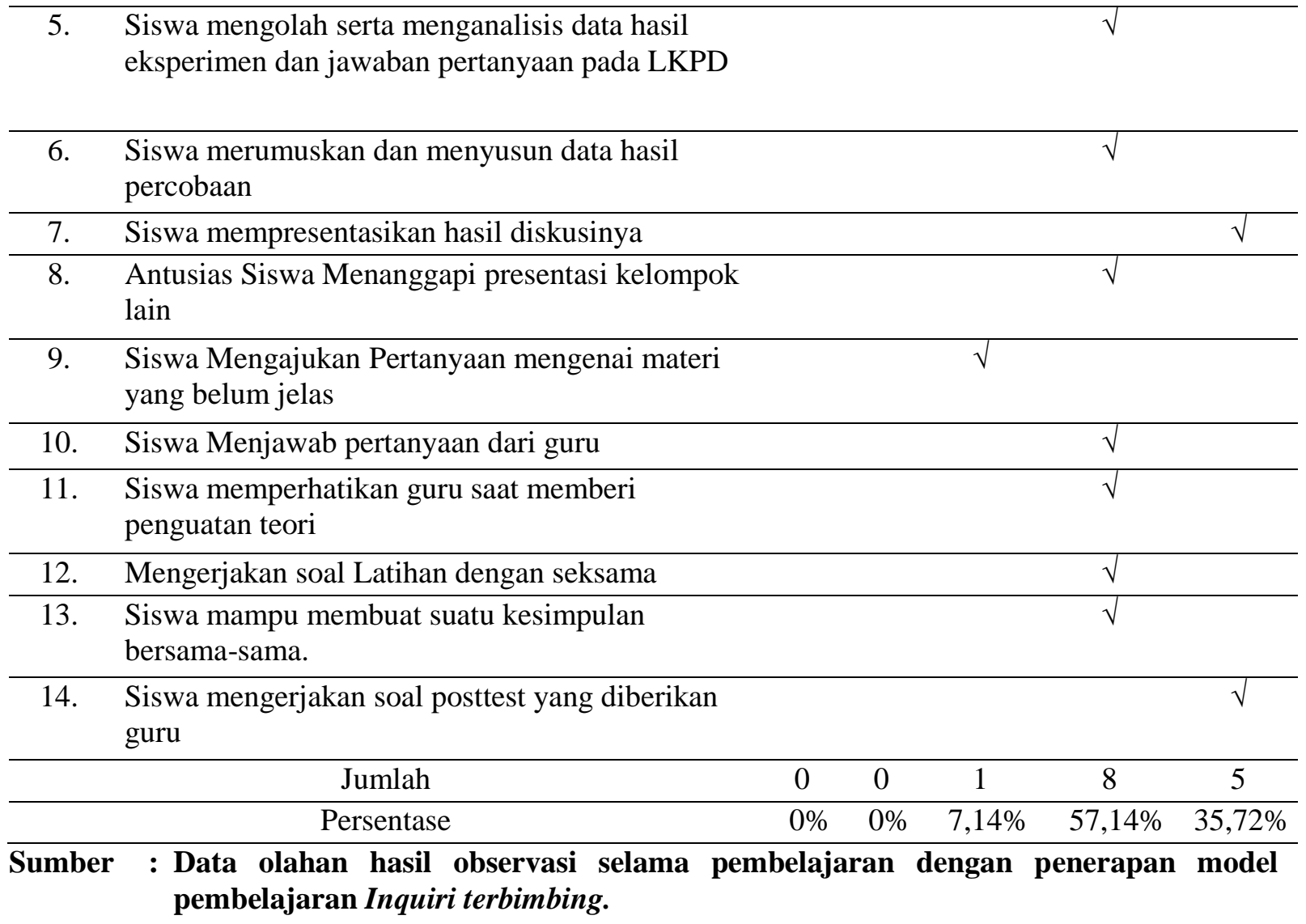

Keterangan untuk hasil observasi SK (sangat kurang), K (kurang), S (sedang), B (baik) dan SB (sangat baik). Berdasarkan Tabel 4.6. di atas, menunjukkan rata-rata aktivitas siswa selama pembelajaran dengan penerapan model pembelajaran Inquiri terbimbing pada konsep sistem ekskresi pada manusia terlihat aktif, dimana kegaiatan yang dilakukan siswa pada kategori kurang $(7,14 \%)$, kategori baik $(57,14 \%)$ dan pada ketegori sangat baik $(35,72 \%)$ jadi dapat disimpulkan bahwa hasil observasi terhadap kegiatan yang dilakukan siswa selama pembelajaran sudah dilakukan dengan baik. Jadi penerapan model pembelajaran Inquiri terbimbing pada konsep sistem ekskresi pada manusia di SMP Negeri 2 Kota Banda Aceh dapat membuat siswa menjadi lebih aktif dan semangat dalam belajar dibandingkan dengan menggunankan metode konvensional.

\section{Pembahasan}

Berdasarkan data yang telah dikumpulkan dan telah dianalisis serta dilakukan penguji hipotesis, menunjukan bahwa nilai t-hitung $(2,63)>$ t-tabel $(1.68023)$ pada taraf signifikan $\alpha(0,05)=(44=1.67528)$. sehingga diperoleh $t_{\text {hitung }}>t_{\text {tabel }}$ maka Ha diterima.
Ternyata pemahaman belajar siswa pada pembelajaran konsep sistem ekskresi pada manusia lebih meningkat dengan penerapan model pembelajaran Inquiri terbimbing dibandingkan dengan menggunakan metode konvensional terhadap siswa kelas VIII SMP Negeri 2 Kota Banda Aceh dalam bidang studi pendidikan biologi pada konsep sistem ekskresi pada manusia. Model inquiry merupakan model pembelajaran aktif yang dapat diterapkan didalam kelas. Proses pembelajaran menggunakan Model inquiry dalam penelitian ini menggunakan inquiry terbimbing. Dimana guru mempunyai peran untuk membimbing siswa yang masih menjadi pemula. Inquiry terbimbing ini tidak semua materi pembelajaran siswa yang merumuskan masalahnya.

Berdasarkan analisis di atas, telah terbukti bahwa terdapat perbedaan yang signifikan antara model inquiry terbimbing dan metode konvensional dalam meningkatkan hasil belajar siswa pada pembelajaran biologi konsep sistem ekskresi pada manusia di SMP Negeri 2 Kota Banda Aceh. Hal yang menyebabkan model inquiry terbimbing memiliki rerata dan peningkatan lebih tinggi dibandingkan dengan metode konvensional 
dikarenakan model inquiry terbimbing lebih membawa siswa aktif di dalam pembelajaran. Meskipun diberikan materi yang sama dengan waktu yang sama pula, namun di dalam model inquiry terbimbing siswa diberikan contohcontoh kasus, di mana siswa dilatih untuk mencari dan menemukan masalah yang ada. Sedangkan pada metode konvensional siswa hanya terpaku pada penjelasan guru dan siswa kurang aktif dalam pembelajaran.

\section{Pembahasan hasil Observasi Pembelajaran}

Dari hasil observasi pembelajaran menunjukkan bahwa nilai rata-rata aktivitas siswa selama pembelajaran dengan penerapan model Inquiri terbimbing pada konsep sistem ekskresi pada manusia tergolong baik, hal ini terlihat dari aktivitas siswa dari setiap kegiatan, rata-rata aktivitas siswa selama pembelajaran dengan penerapan model pembelajaran Inquiri terbimbing pada konsep sistem ekskresi pada manusia terlihat aktif, dimana kegaiatan yang dilakukan siswa pada kategori kurang $(7,14 \%)$, kategori baik $(57,14 \%)$ dan pada ketegori sangat baik $(35,72 \%)$ jadi dapat disimpulkan bahwa hasil observasi terhadap kegiatan yang dilakukan siswa selama pembelajaran sudah dilakukan dengan baik. Jadi penerapan model pembelajaran Inquiri terbimbing pada konsep sistem ekskresi pada manusia dapat membuat siswa menjadi lebih aktif dan semangat dalam belajar dibandingkan dengan menggunankan metode konvensional (Hasil observasi pembelajaran di SMP Negeri 2 Banda Aceh 2016).

\section{KESIMPULAN}

Berdasarkan hasil penelitian dan analisis data yang telah dilakukan di kelas VIII SMP Negeri 2 Kota Banda Aceh, dapat diambil kesimpulan sebagai berikut:

1. Adanya perbedaan yang positif antara penerapan model Inquiri terbimbing dengan metode konvensional terhadap hasil belajar siswa pada konsep sistem ekskresi pada manusia, hal ini dibuktikan dengan perolehan rata-rata selisih (gain) pada kelas eksperimen perolehan rata-rata selisih nilai adalah 14,24 dengan nilai $\mathrm{N}$-gain 0,44 dan kelas kontrol adalah 5,42 dengan nilai $\mathrm{N}$-gain 0,27 .
2. Hasil uji t diperoleh nilai $t_{\text {hitung }}$ sebesar 2,14 dan $t_{\text {tabel }} 1.68023$ sehingga diketahui $\mathrm{t}_{\text {hitung }}>\mathrm{t}_{\text {tabel }}$, maka $\mathrm{H}_{\mathrm{a}}$ diterima pada taraf signifikan $\alpha=0,05$ $\mathrm{dan} d \mathrm{k}=(22+24-2=44)$. Dengan demikian dapat disimpulkan adanya perbedaan hasil belajar siswa antara penerapan model Inquiri terbimbing dengan metode konvensional terhadap siswa kelas VIII SMP Negeri 2 Kota Banda Aceh.

3. Berdasarkan hasil observasi pembelajaran terhadap aktivitas siswa selama pembelajaran dengan penerapan model pembelajaran Inquiri terbimbing pada konsep sistem ekskresi pada manusia terlihat aktif, dimana kegaiatan yang dilakukan siswa pada kategori kurang $(7,14 \%)$, kategori baik $(57,14 \%)$ dan pada ketegori sangat baik $(35,72 \%)$. Jadi penerapan model pembelajaran Inquiri terbimbing pada konsep sistem ekskresi pada manusia dapat membuat siswa menjadi lebih aktif dan semangat dalam belajar dibandingkan dengan menggunankan metode konvensional.

\section{UCAPAN TERIMA KASIH}

Penulis ucapkan terimakasih kepada semua pihak yang telah membantu dan memberikan dukungan secara penuh dalam kegiatan penelitian ini.

\section{DAFTAR PUSTAKA}

Andriani, N. dkk. 2011. Efektifitas Penerapan Pembelajaran Inkuiri Terbimbing (Guided Inquiry) pada Mata Pelajaran Fisika Pokok Bahasan Cahaya di Kelas VIII SMP Negeri 2 Muara Padang. Prosiding Simposium Nasional Inovasi Pembelajaran dan Sains 2011 (SNIPS 2011). 133-137.

Arikunto, S. 2006. Dasar-dasar Evaluasi Pendidikan. Jakarta: Bumi Aksara.

Darmaningtyas. 2005. Ilusi tentang Guru dan Profesionalisme. Yogyakarta: Universitas Sanata Dharma. 
Departemen Pendidikan Nasional. 2008. Kamus Besar Bahasa Indonesia Pusat Bahasa. Jakarta: PT. Gramedia Pustaka Utama.

Djohar. 2010. Definisi, Refitalisasi, dan Reaktualisasi Pendidikan di Indonesia. Yogyakarta: FMIPA UNY.

Joyce, Marsha Weil, Emily Calhoun. 2009. Models Of Teaching: Model-Model Pengajaran. Yogyakarta. Pustaka Pelajar.

Meltzer, D.E. 2002. The Relationship between Mathematics Preparation and Conceptual Learning Grains in Physics: A Possible "Hidden Variable" in Diagnostice Pretest Scores. American Journal Physics, Vol 70 (12), 27 halaman.

Muyasa, E. 2003. Menjadi Guru Professional Menciptakan Pembelajaran Kreatif dan Menyenangkan. Bandung: PT. Remaja Rosdakarya.

Nana Sudjana. 1987. Cara Belajar Siswa Aktif. Bandung : CV. Sinar Baru.

Nana Syaodih Sukmadinata. 2009. Metode Penelitian Pendidikan. Bandung: Rosdakarya.

Roestiyah. 2008. Strategi Belajar Mengajar. Jakarta: PT. Rineka Cipta.

Sanjaya. 2006. Strategi Pembelajaran Berorientasi Standar Proses Pendidikan. Jakarta: Prenada Media Group.

Slameto 2010. Belajar dan Faktor-Faktor yang Mempengaruhinya. Jakarta: Rineka Cipta.

Subroto, B. Suryo. 2002. Proses Belajar Mengajar di Sekolah. Jakarta: Rineka Cipta

Sudjana. 2005. Metode Statistika Edisi ke-6. Bandung : Tarsito.
Sugiyono. 2010. Statistika untuk Penelitian. Bandung: Alfabeta.

Sugiyono. 2011. Metode Penelitian Kuantitatif Kualitatif dan $R \& D$. Bandung: Alfabeta.

Suharsimi Arikunto. 2009. Dasar-Dasar Evaluasi Pendidikan. Jakarta: Bumi Aksara.

Undang-Undang Republik Indonesia No. 4 Tahun 1982 Tentang Ketentuan Pokok Pengelolaan Lingkungan Hidup. Lembaran Negara Republik Indonesia Tahun 1982 Nomor 12.

W. Gulo. 2002. Strategi Belajar Mengajar. Jakarta: PT. Gramedia Widiasarana Indonesia.

Wina Sanjaya. 2011. Strategi Pembelajaran Berorientasi Standar Proses Pendidikan. Jakarta: Kencana. 